\title{
SELECTION AND TREATMENT OF DATA FOR RADIOCARBON CALIBRATION: AN UPDATE TO THE INTERNATIONAL CALIBRATION (INTCAL) CRITERIA
}

\author{
Paula J Reimer ${ }^{1,2} \cdot$ Edouard Bard $^{3} \cdot$ Alex Bayliss $^{4} \cdot \mathrm{J} \mathrm{Warren} \mathrm{Beck}^{5}$ • Paul G Blackwell ${ }^{6}$. \\ Christopher Bronk Ramsey ${ }^{7}$ David M Brown ${ }^{1}$ Caitlin E Buck ${ }^{6}$ R Lawrence Edwards ${ }^{8} \bullet$ \\ Michael Friedrich $^{9,10} \bullet$ Pieter M Grootes $^{11} \bullet$ Thomas P Guilderson $^{12,13} \bullet$ Haflidi Haflidason ${ }^{14 \dagger} \bullet$ \\ Irka Hajdas ${ }^{15} \bullet$ Christine Hatté ${ }^{16 \dagger} \bullet$ Timothy J Heaton $^{6} \bullet$ Alan G Hogg $^{17} \bullet$ Konrad A Hughen $^{18} \bullet$ \\ K Felix Kaiser ${ }^{19,20^{*}} \cdot$ Bernd Kromer $^{10} \bullet$ Sturt W Manning ${ }^{21} \bullet$ Ron W Reimer ${ }^{1} \bullet$ \\ David A Richards ${ }^{22} \bullet$ E Marian Scott $23 \uparrow \bullet$ John R Southon ${ }^{24} \bullet$ Christian S M Turney ${ }^{25} \bullet$ \\ Johannes van der Plicht ${ }^{26,27}$
}

\begin{abstract}
High-quality data from appropriate archives are needed for the continuing improvement of radiocarbon calibration curves. We discuss here the basic assumptions behind ${ }^{14} \mathrm{C}$ dating that necessitate calibration and the relative strengths and weaknesses of archives from which calibration data are obtained. We also highlight the procedures, problems, and uncertainties involved in determining atmospheric and surface ocean ${ }^{14} \mathrm{C} /{ }^{12} \mathrm{C}$ in these archives, including a discussion of the various methods used to derive an independent absolute timescale and uncertainty. The types of data required for the current IntCal database and calibration curve model are tabulated with examples.
\end{abstract}

${ }^{1}$ 14CHRONO Centre for Climate, the Environment and Chronology, School of Geography, Archaeology and Palaeoecology, Queen's University Belfast BT7 1NN, United Kingdom.

${ }^{2}$ Corresponding author. Email:p.j.reimer@qub.ac.uk.

${ }^{3}$ CEREGE, Aix-Marseille University, CNRS, IRD, Collège de France, Technopole de l'Arbois BP 80, 13545 Aix en Provence Cedex 4, France.

${ }^{4}$ English Heritage, 1 Waterhouse Square, 138-142 Holborn, London EC1N 2ST, United Kingdom.

${ }^{5}$ Department of Physics, University of Arizona, Tucson, Arizona 85721, USA.

${ }^{6}$ School of Mathematics and Statistics, University of Sheffield, Sheffield S3 7RH, United Kingdom.

${ }^{7}$ Research Laboratory for Archaeology and the History of Art, University of Oxford, Dyson Perrins Building, South Parks Road, Oxford OX1 3QY, United Kingdom.

${ }^{8}$ Department of Earth Sciences, University of Minnesota, Minneapolis, Minnesota 55455-0231, USA

${ }^{9}$ Institute of Botany (210), Hohenheim University, D-70593 Stuttgart, Germany.

${ }^{10}$ Heidelberger Akademie der Wissenschaften, Im Neuenheimer Feld 229, D-69120 Heidelberg, Germany

${ }^{11}$ Institute for Ecosystem Research, Christian-Albrechts-Universität zu Kiel 24098, Germany.

${ }^{12}$ Center for Accelerator Mass Spectrometry L-397, Lawrence Livermore National Laboratory, Livermore, California 94550 , USA.

${ }^{13}$ Ocean Sciences Department, University of California-Santa Cruz, Santa Cruz, California 95064, USA.

${ }^{14}$ Department of Earth Science, University of Bergen, N-5007 Bergen, Norway.

${ }^{15}$ Labor für Ionenstrahlphysik, ETH, 8092 Zurich, Switzerland.

${ }^{16}$ Laboratoire des Sciences du Climat et de l'Environnement, UMR8212 CEA-CNRS-UVSQ, Domaine du CNRS, F-91198 Gif-sur-Yvette, France.

${ }^{17}$ Radiocarbon Dating Laboratory, University of Waikato, Private Bag 3105, Hamilton, New Zealand.

${ }^{18}$ Department of Marine Chemistry \& Geochemistry, Woods Hole Oceanographic Institution, Woods Hole, Massachusetts 02543, USA.

${ }^{19}$ Swiss Federal Institute for Forest, Snow and Landscape Research WSL, Zurcherstr. 111, 8903 Birmensdorf, Switzerland. ${ }^{20}$ Department of Geography, University of Zurich-Irchel, 8057 Zurich, Switzerland.

${ }^{21}$ Malcolm and Carolyn Wiener Laboratory for Aegean and Near Eastern Dendrochronology, Cornell Tree Ring Laboratory, Cornell University, Ithaca, New York 14853, USA.

${ }^{22}$ School of Geographical Sciences, University of Bristol, Bristol BS8 1SS, United Kingdom.

${ }^{23}$ School of Mathematics and Statistics, University of Glasgow, Glasgow G12 8QQ, Scotland.

${ }^{24}$ Department of Earth System Science, University of California-Irvine, Irvine, California 92697, USA.

${ }^{25}$ Climate Change Research Centre, School of Biological, Earth and Environmental Sciences, University of New South Wales, Sydney, NSW 2052, Australia.

${ }^{26}$ Centrum voor Isotopen Onderzoek, Rijksuniversiteit Groningen, Nijenborgh 4, 9747 AG Groningen, the Netherlands.

${ }^{27}$ Faculty of Archaeology, Leiden University, P.O. Box 9515, 2300 RA Leiden, the Netherlands.

*Deceased.

$\dagger$ IntCal Oversight Committee members. 


\section{INTRODUCTION}

Radiocarbon dating provides the chronological basis for much archaeological and geoscientific research in the late Quaternary period. ${ }^{14} \mathrm{C}$ age, however, does not provide a calendrical age directly but must be corrected for variations in the ${ }^{14} \mathrm{C} /{ }^{12} \mathrm{C}$ ratio of the atmosphere, ocean, or other reservoir where the sample grew or was formed. This is done by comparison (i.e. calibration), with curves derived from ${ }^{14} \mathrm{C}$ ages of samples that have been calendrically dated by alternative and independent means. In the best-case scenario, the calendar age of the independently dated samples should be known precisely and absolutely. Numerous such calibration curves have been constructed over the years (see reviews in Klein et al. 1982; Becker 1992; Reimer and Reimer 2007). These have evolved through time as new calibration data sets have become available and improved data analysis techniques have been implemented. The importance of a standardized calibration curve for specific reservoirs, which, amongst other advantages, makes direct comparison between studies feasible, has been acknowledged by the international ${ }^{14} \mathrm{C}$ community (Klein et al. 1982; Turney et al. 2006).

The IntCal Working Group (IWG) grew out of earlier collaborations between researchers who provided the data used to construct the 1993 and 1998 calibration curves (Stuiver and Reimer 1993; Stuiver et al. 1998a,b). The IWG has provided 2 major updates and extensions to the terrestrial and marine calibration curves, which have been ratified at International Radiocarbon conferences (Hughen et al. 2004; Reimer et al. 2004, 2009). The calibration curves presented in this issue were ratified in 2012 at the 21st International Radiocarbon Conference in Paris. The IWG comprises researchers actively interested in a wide variety of facets associated with ${ }^{14} \mathrm{C}$ calibration, including the production of calibration data sets, assessment of the variability in ${ }^{14} \mathrm{C} /{ }^{12} \mathrm{C}$ ratios in specific reservoirs or at specific localities over time, statistical interpretation of information from a varied ensemble of large data sets, or application of calibration in archaeological and environmental studies. The IWG does not have a fixed composition and consists of individuals who are working actively to refine ${ }^{14} \mathrm{C}$ calibration including major data providers, modelers, and those who have been involved in previous IntCal exercises. The IntCal Oversight Committee was nominated and elected by the user community in 2008 and contributes to the decision-making processes of the IWG.

The IWG published criteria for the inclusion of data into the international ${ }^{14} \mathrm{C}$ calibration curves in Reimer et al. (2002) to promote discussion and involvement from the wider community in the process of producing consensus calibration curves. Over the course of the past decade, advances in statistical methods used to construct the calibration curve (Blackwell and Buck 2008; Heaton et al. 2009; Niu et al. 2013, this issue), and careful refinement of the scientific methods used to produce calibration data, mean that it is now possible to quantify and formally allow for a much wider range of sources of uncertainty and offset from a diverse range of archives. We are acutely aware that there will be further advances in this field, with inevitable adjustment of curves as more calibrationquality data emerge and alternative compilation methods are promoted. Critical to such efforts will be the adoption of a consistent and thorough approach to documentation of all sources of uncertainty and methodological procedures and a range of metadata to enhance the long-term value of individual data sets. Given the recent rapid increase in the number of calibration data sets and the inevitable changes, the IWG feels this is an appropriate time to provide updated criteria for calibration-quality data, and the types of metadata desirable for data sets contributing to future calibration curves.

We will discuss the following in this article:

1. Basic assumptions behind ${ }^{14} \mathrm{C}$ dating that necessitate calibration;

2. Archives from which calibration data are obtained; 
3. Procedures used to determine the sought-after ${ }^{14} \mathrm{C} /{ }^{12} \mathrm{C}$ (of atmosphere or mixed surface ocean); 4. Methods to derive an independent absolute timescale for the ${ }^{14} \mathrm{C}$ calibration data obtained from the respective archives and the associated uncertainties.

\section{RADIOCARBON DATING AND CALIBRATION}

An uncalibrated ${ }^{14} \mathrm{C}$ age calculation includes several assumptions: 1) Atmospheric ${ }^{14} \mathrm{C} /{ }^{12} \mathrm{C}$ has been constant through time; 2) The carbon reservoir in which the sample grew or was formed had the ${ }^{14} \mathrm{C} /$ ${ }^{12} \mathrm{C}$ composition of the atmosphere or had a known offset with respect to it; and 3) The sample came from a closed system that has not exchanged carbon with its surroundings since formation. ${ }^{14} \mathrm{C}$ calibration is intended to correct for any violation of the first 2 assumptions through the use of curves constructed from measurements on appropriate archives, which also must satisfy the last assumption.

The Northern Hemisphere atmospheric reservoir is the best understood, with pre-industrial ${ }^{14} \mathrm{CO}_{2}$ relatively well mixed, in theory, and derived ${ }^{14} \mathrm{C}$ ages expected to deviate significantly at only high altitude or latitude (Braziunas et al. 1995). Regional differences on the order of $10-20{ }^{14} \mathrm{C}$ yr have been observed due to coastal upwelling of older, ${ }^{14} \mathrm{C}$-depleted ocean carbon, or due to growing-season differences (Stuiver and Braziunas 1998; Kromer et al. 2001; Dee et al. 2010). The Southern Hemisphere atmosphere has a stronger latitude dependency due to the larger ocean to land surface area ratio combined with the upwelling of older water around Antarctica and the strong circumpolar winds (Braziunas et al. 1995). At mid-latitudes, the Southern Hemisphere ${ }^{14} \mathrm{C}$ has differed from the Northern Hemisphere, on average, by approximately $45{ }^{14} \mathrm{C}$ yr for the last 2 millennia, but varies between -12 and $+83{ }^{14} \mathrm{C}$ yr (Hogg et al. 2009, 2011). The atmospheric record in low latitudes in both the Northern and Southern hemispheres is also complicated by the Intertropical Convergence Zone (ITCZ), where the winds from the 2 hemispheres come together, making atmospheric mixing across this zone irregular. The position of the ITCZ varies with the changing seasons and over longer time periods, so some low-latitude locations may sporadically reflect either Northern or Southern atmospheric ${ }^{14} \mathrm{C}$ (e.g. Hua et al. 2004; Wang et al. 2004).

The carbon in the surface ocean (marine mixed layer) is a mixture of $\mathrm{CO}_{2}$ recently exchanged with the atmosphere and older $\mathrm{CO}_{2}$ diffused upwards from the thermocline and the deep ocean. In the current ocean circulation regime, this produces an average ${ }^{14} \mathrm{C}$ offset from the atmosphere of approximately $400 \mathrm{yr}$ (called the global ocean reservoir offset), but the actual offset varies with location, especially in regions of upwelling of older ocean water such as Antarctica, the west coasts of continents, or in regions where large baroclinic eddies may be generated (Bard 1988; Stuiver and Braziunas 1993; Levin and Hesshaimer 2000). In general, the range of decadal-scale ${ }^{14} \mathrm{C} /{ }^{12} \mathrm{C}$ variations in the marine mixed layer is attenuated relative to that observed in the atmosphere, although some corals have been shown to track the atmosphere closely (Druffel et al. 2008). The reservoir offset is also variable over time, particularly during periods when ocean circulation was different from present, such as during the last glaciation and in the North Atlantic during the Younger Dryas and Heinrich cold events (Bard et al. 1994; Austin et al. 1995, 2011; Haflidason et al. 2000; Voelker et al. 2000; Bondevik et al. 2006). These reservoir offsets have been simulated in modeling exercises (e.g. Butzin et al. 2005; Franke et al. 2008; Singarayer et al. 2008; Matsumoto and Yokoyama 2013).

\section{ARCHIVE SELECTION}

Several factors challenge the exercise of deriving a robust calibration curve from a suite of calibration data sets. Key amongst these factors are the integrity of the samples used in the ${ }^{14} \mathrm{C} /{ }^{12} \mathrm{C}$ data set (e.g. closed systems, stratigraphically consistent) and secondly, the quality of the independent time- 
scale. Much work has been expended in the past to generate high-quality ${ }^{14} \mathrm{C}$ measurements on records that were later shown to deviate from other calibration records well beyond statistical uncertainties. The Swedish varved clays (Wohlfarth and Possnert 2000) and the initial single Lake Suigetsu core (Kitagawa and van der Plicht 1998; Staff et al. 2010) are 2 examples where hiatuses in sediments caused deviations in the timescales. Therefore, care must be taken in selecting an archive and establishing a reliable timescale, although problems may not be recognized until comparisons to other records are made.

When selecting an archive as a representative recorder of ${ }^{14} \mathrm{C}$ variation for calibration of one of the carbon reservoirs (i.e. atmosphere or ocean), the relationship between what is measured and how an atmospheric or ocean mixed layer signal was incorporated into this sample must be considered (e.g. ocean reservoir age, dead carbon fraction, seasonality, bioturbation). For any marine archive, the regional reservoir offset and its variability over time must be evaluated, regardless of whether the data are used to construct an "atmospheric equivalent" or a normalized "global" marine calibration curve. Records should originate from hydrodynamically simpler regions (e.g. away from coastal and open ocean upwelling zones or where the currents are complex and climatically sensitive).

In general, high-resolution data (e.g. samples formed in $10 \mathrm{yr}$ or less in the Holocene and deglaciation and $50 \mathrm{yr}$ or less in the glacial period) are preferred to low-resolution data ( $>50 \mathrm{yr}$ resolution), because of the extra information that they carry, particularly regarding any inversions or rapid inflections in the curve. In addition, clear evidence of reproducibility needs to be supplied and, in particular, within the uncertainties given (an overlap with existing calibration data is useful in confirming this). There must also be quality control on the associated calendar age estimates, with sufficient information provided on how errors were constructed, to offer confidence that efforts were made to identify and, where practical, quantify all sources of uncertainty on the observations jointly as well as individually.

\section{Tree Rings}

Tree rings are ideal recorders of atmospheric ${ }^{14} \mathrm{C}$ and are most useful in estimating the calibration curves if the ring widths series of the relevant trees can be compiled up to the present as an independent absolute chronology, or be robustly correlated to an independently established tree-ring chronology of matchable species and climatically similar region (Becker 1992). In such cases, tree rings provide a reliable absolute annually resolved chronology as opposed to a floating one. Trees from the mid- and high latitudes - where sites of the long chronologies are located - reliably form exactly 1 ring per year (e.g. St. George et al. 2013). Sporadic missing or double rings can occur in some species relevant to long dendrochronologies but can be detected through use of multiple replications of the tree-ring series (Spurk et al. 1998; Palmer et al. 2006). Therefore, multiply-replicated tree-ring chronologies are generally thought to be one of the most reliable and accurate timescales (Becker 1992).

The cellulose in tree rings is formed primarily from photosynthesis in a single growing season with a component coming from carbon stored from previous years (Grootes et al. 1989). Alpha- or holocellulose extraction has been used for many years but not for all tree-ring calibration samples. Measurements on material extracted from tree rings of Douglas fir growing through the peak of atmospheric nuclear weapons testing in the early 1960s indicated deposition of material with high ${ }^{14} \mathrm{C}$ activity into wood formed up to $40 \mathrm{yr}$ earlier (Stuiver and Quay 1981). The de Vries method of sample pretreatment (heating in $\mathrm{NaOH}$ and $\mathrm{HCl}$ solutions; de Vries and Barendsen 1952) is often used for tree-ring ${ }^{14} \mathrm{C}$ measurements but does not remove all of the compounds such as lignin that may be incorporated into the tree-ring wood after cell formation (Cain and Suess 1976). However, the ${ }^{14} \mathrm{C}$ activity of de Vries-treated Douglas fir wood did not differ statistically from those treated to alpha- 
cellulose, except for rings formed within $20 \mathrm{yr}$ of the nuclear weapons testing peak (Stuiver and Quay 1981). Therefore, except for unusual periods of extreme, rapid change in atmospheric ${ }^{14} \mathrm{C}$ content (like the bomb pulse) or at the older end of the ${ }^{14} \mathrm{C}$ timescale (Hogg et al. 2006; Turney et al. 2010), the de Vries and alpha-cellulose pretreatment methods produce only small differences in ${ }^{14} \mathrm{C}$ abundance generally within measurement uncertainty.

\section{Terrestrial Macrofossils}

Terrestrial macrofossils can also be suitable for direct recording of atmospheric ${ }^{14} \mathrm{C}$ if an independent timescale can be established (e.g. Bronk Ramsey et al. 2012), although it is also recognized that organic material can sometimes remain in the landscape for a considerable length of time before being deposited, particularly in high-latitude environments, or be reworked from earlier deposits (Abbott and Stafford 1996; Oswald et al. 2005). For this reason, fragile leaves and plant fragments without evidence of reworking are the preferred material (Barnekow et al. 1998; Turney et al. 2000). In lake sediments, preference should be for intact fragile terrestrial macrofossils. Some emergent aquatic plants take up some $\mathrm{CO}_{2}$ from the sediments and shorter riparian plants can utilize $\mathrm{CO}_{2}$ evading from the surface water, either of which could result in older apparent ${ }^{14} \mathrm{C}$ ages due to incorporation of geological or remineralized organic carbon (Maberly and Spence 1983; Boston 1986; Hatté and Jull 2007). In tectonically active regions, lakes may also be affected by magmatic $\mathrm{CO}_{2}$ devoid of ${ }^{14} \mathrm{C}$. In such lakes, wind-blown terrestrial macrofossils are typically free of old $\mathrm{C}$ (e.g. Lago di Monticcio, Hajdas et al. 1998). While terrestrial pollen may also be extracted from sediments for ${ }^{14} \mathrm{C}$ analysis, aquatic pollen spores and non-pollen palynomorphs, which may be subject to a lake reservoir effect, and reworked pollen are difficult to avoid, though new methods offer considerable promise (Tennant et al. 2013).

For terrestrial macrofossils, an independent, precise, and accurate timescale for sediments can be difficult to establish, and usually requires annually laminated (varved) sediments (see section "Varve Counting") in combination with tephrochronology and/or correlation of preserved and assumed regionally synchronous climate signals. A combination of high-resolution micro-XRF (Marshall et al. 2012) with microscopic sedimentary analysis and an algorithm to interpolate indistinguishable varves (Schlolaut et al. 2012), such as those used for the Suigetsu core SG06 (Bronk Ramsey et al. 2012), may provide floating chronologies of sufficient quality that they can be made absolute by anchoring them to the secure part of the atmospheric tree-ring calibration curve.

\section{Corals}

Aragonitic coral species that grow near the surface of the ocean have provided ${ }^{14} \mathrm{C}$ records of the marine mixed layer in specific regions (e.g. Bard et al. 1990a for the Atlantic; Edwards et al. 1993 for the Pacific). Many ${ }^{14} \mathrm{C}$ measurements on U-Th dated corals have been included in the international ${ }^{14} \mathrm{C}$ calibration curves since 1993. Criteria for screening for corals that meet the closed system requirement have been discussed in detail previously (Reimer et al. 2002, 2004, 2006; Chiu et al. 2005 ) and relate to the preservation of the primary mineralogy and negligible gain or loss of $\mathrm{U}, \mathrm{Th}$, or $\mathrm{C}$ isotopes by any means other than radioactive decay since the time of formation. The IntCal coral criteria are summarized below.

Any calcite present in the aragonitic corals is presumed to be secondary in nature (Chappell et al. 1974). Depending on the environment, surface contamination from calcite can be older, younger, or contemporaneous to the coral, as in the case of overgrowths by coralline algae and/or by microbialites (e.g. Seard et al. 2010). As such, quantitative X-ray diffraction measurements should show $<1 \%$ calcite. This implies an even lower detection limit, typically around $0.2 \%$ (e.g. Chiu et al. 
2005; Sepulcre et al. 2009). Alternatively, independent evidence of the reliability of the sample material should be produced.

The geochemistry of calcite overgrowths influences whether it is more soluble (high $\mathrm{Mg}$ ) or less soluble (low Mg) than aragonite (Morse and Mackenzie 1990; Railsback 2006; Andersson et al. 2008; Andersson and Mackenzie 2011), but in most cases leaching removes surface contamination (Bard et al. 1990b; Burr et al. 1992; Yokoyama et al. 2000; Durand et al. 2013, this issue). We therefore recommend that each coral sample be acid-leached prior to ${ }^{14} \mathrm{C}$ dating to remove surface contamination, that the residual calcite content after leaching be below $1 \%$, and that measured values are provided with the ${ }^{14} \mathrm{C}$ age. We advise that specific tests are performed to quantify the influence of residual contaminations at a particular sampling site of corals, notably the age of secondary carbonates (calcite or aragonite) and their efficient removal by leaching or other techniques. Future research may lead to the adoption of new stringent criteria (general or site-specific).

The U concentration of fossil corals should be similar to modern specimens taking into account the variability observed today (interspecific differences and dependency to environmental parameters such as growth temperature). Initial ${ }^{234} \mathrm{U} /{ }^{238} \mathrm{U}$ values of Holocene and deglacial fossil corals should lie within the modern and recent corals range corresponding to $\delta^{234} \mathrm{U}=147 \pm 7 \%$ ( 3 s.d.). Last glacial period corals tend to record $\delta^{234} U_{\text {initial }}$ values $7-10 \%$ lower than modern (Cutler et al. 2004; Esat and Yokoyama 2006; Durand et al. 2013, this issue). Whether this difference results from diagenesis or a shift in the marine value is not absolutely clear (Cutler et al. 2004; Robinson et al. 2004; Esat and Yokoyama 2006). However, to allow for the latter possibility, corals $>17 \mathrm{kyr}$ BP should be within the range of $142 \pm 8 \%$ ( 3 s.d.). Note that the higher end of this range encompasses the modern value.

\section{Forams}

The carbonate shells of planktonic foraminifera can provide a ${ }^{14} \mathrm{C}$ record of the marine mixed layer in specific regions, depending on the preferred depth habitat and seasonal life cycle. With forams from non-varved sediments, the issue of bioturbation must be considered also (Bard et al. 1987; Thomson et al. 1995; Löwemark and Grootes 2004); hence, high sedimentation records (e.g. over $20 \mathrm{~cm} / 1000 \mathrm{yr}$ ) are preferred for inclusion in consensus calibration curves. It is also recognized that the deposition of older reworked shells can be problematic (Heier-Nielsen et al. 1995), although abundance and the degree of preservation of the chosen species can be used as important indicators of reworking (Barker et al. 2007). With the exception of varved sediments, high-resolution chronologies for foram-based records must be derived from established atmospheric teleconnections with minimal lag to independent and accurately dated archives such as ice cores with annual layer counting or speleothems dated by U-Th (Voelker et al. 2000; Bard et al. 2004; Hughen et al. 2006). Uncertainties of the derived absolute timescale should be estimated from propagation of the uncertainties of both the original absolute chronology (see section "Uranium-Thorium Dating") and of the correlation process between both climatic signals (see section "Tie-Pointed Timescales") (Hughen et al. 2006; Bard et al. 2013, this issue; Heaton et al. 2013, this issue). As for corals, the use of a mixedlayer record as an atmospheric equivalent requires quantification of the local surface ${ }^{14} \mathrm{C}$ reservoir age and its possible variations over time (Bard 1988; Stuiver and Braziunas 1993; Sarnthein et al. 2007, 2013).

\section{Speleothems}

Speleothems are secondary mineral deposits that precipitate from drip water in caves. Calcite and aragonite, polymorphs of calcium carbonate, dominate the various mineral formations (e.g. stalag- 
mites, stalactites, and flowstones), with coarsely crystalline examples of calcite the most likely to be closed systems and thus suitable for ${ }^{14} \mathrm{C}$ calibration. At the time of formation, $\mathrm{U}$ from the ground water is coprecipitated in calcite and aragonite, with negligible Th. The ingrowth of the radiogenic daughters ${ }^{230} \mathrm{Th}$ and ${ }^{231} \mathrm{~Pa}$ can be used to provide an independent timescale using U-Th-Pa methods. Dissolved inorganic carbon in cave drip water is sourced from a combination of root respiration, soil organic matter decomposition, the cave air, and dissolution of bedrock (Genty et al. 2001; Baldini 2010). Decomposition of soil organic matter may have a time lag between growth of the plants and its remineralization and incorporation in groundwater, affecting ${ }^{14} \mathrm{C}$ levels in the speleothem, particularly during periods when climate and vegetation changed (Genty et al. 2001). This effect is likely to contribute offsets of years to perhaps decades, but is minor compared with the expected contribution of ${ }^{14} \mathrm{C}$-free carbonate from the bedrock - the dead carbon fraction (DCF) or dead carbon proportion (dcp), which can vary dramatically between different locations in the cave, and sometimes during the period of growth (Genty et al. 2001). For speleothems, a correction for DCF and its variability through time has to be made to estimate "atmospheric equivalent" ${ }^{14} \mathrm{C}$ concentration for calibration purposes. DCF is usually estimated by analyzing a section of the speleothem that overlaps with the tree-ring portion of the calibration curve. The mean ${ }^{14} \mathrm{C}$ offset from the established calibration curve is then used as the DCF. An uncertainty term associated with the variance between the speleothem and established calibration curve, which is usually as large as or larger than the analytical uncertainty terms, must also be added quadradically to the other analytical uncertainties. Considering the potential effect of the interplay between vegetation and climate (temperature, precipitation) on soil carbon and drip rates, an assumed constant ${ }^{14} \mathrm{C}$ offset is probably a simplification of the actual situation. Establishing the reliability of the absolute timescale obtained by U-Th dating requires a careful evaluation similar to that described above for corals, based on stratigraphic consistency and replicate analysis (see later section for further details on uncertainties associated with U-Th-derived timescales). Age-depth models have been utilized because the speleothem growth rate is non-uniform and subsamples for ${ }^{14} \mathrm{C}$ dating may be obtained at different intervals to those used for U-Th dating. In so doing, then, calendar ages are based on interpolation at depths sampled for ${ }^{14} \mathrm{C}$ determination. Uncertainty of the calendar age for a corresponding ${ }^{14} \mathrm{C}$ age will be influenced by $\mathrm{U}$ Th age errors, density of U-Th determinations along the growth axis, and expected growth rate variation (see also section "Age-Depth Models").

\section{Other Potential Archives}

It is expected that a wider range of data sets will be considered for inclusion in the IntCal database. One possibility is plant material (e.g. trees), charred in volcanic eruptions for which tephra have been dated using ${ }^{40} \mathrm{Ar}^{-39} \mathrm{Ar}$ methods. In such circumstances, the outer tree rings or short-lived organic material are assumed to be contemporaneous with the eruption. This is only feasible in volcanic eruptions with potassium-rich tephra. Care would need to be taken that the plant material was not living close to the active volcano since ${ }^{14} \mathrm{C}$-depleted $\mathrm{CO}_{2}$ can be emitted from volcanic activity (Sulerzhitzky 1971; Rubin et al. 1987; Pasquier-Cardin et al. 1999). Correlation with well-dated (e.g. macrofossils) distal deposits may be the best approach to overcome this problem.

Specific compounds can also be extracted from marine and terrestrial sediments and analyzed, providing an alternative source for marine or atmospheric ${ }^{14} \mathrm{C}$ content. Preference should be given for a compound specific to a single species rather than poorly differentiated compound series (e.g. alkanes) that are a mixture of compounds from different origins (and thus, potentially, different ${ }^{14} \mathrm{C}$ activities). Care should also be taken to ensure an adequate sample size to avoid reduced precision during measurement. As with non-varved terrestrial macrofossil and foraminifera records, the timescale for non-varved sediments must be derived from correlations of climate proxies with inde- 
pendently dated climate series (such as $\delta^{18} \mathrm{O}$ in ice cores or speleothems). The resulting timescale should be tested with event markers, such as tephra horizons, where possible, or checked for plausible sedimentation rates.

\section{PROCEDURES}

\section{${ }^{14} \mathrm{C}$ Sample Pretreatments, Blanks, and Interlaboratory Comparisons}

Sample pretreatments should also account for the chemical and physical structure of the target carbon to ensure that the pretreatment removed any natural contamination and did not add significant levels in the laboratory. This can be a problem especially during alkali treatment for macrofossils (Hatté et al. 2001) or charred organic material (Ascough et al. 2009; Higham et al. 2009; Douka et al. 2010). Pretreatments should follow well-established techniques or demonstrate that the technique used is suitable. The pretreatment should be specified in the metadata (Table 1).

Background or blank determination is necessary to account for any sample processing contamination or machine noise in ${ }^{14} \mathrm{C}$ measurements. Anthracite was commonly measured for the background for organic samples in the past, whereas material closer in morphology and depositional environment to the samples is preferred where possible (e.g. wood or charcoal). Geological calcite may be used when measuring carbonate samples, although here too blank material similar to the sample material is to be preferred. The selection of the background material becomes even more important when measurements are made close to the limit of the ${ }^{14} \mathrm{C}$ method. In situ contamination may be more difficult to remove in some materials, so the use of background samples of similar material may give a more representative blank value. For carbonates such as foraminifera or marine shells, the background may be species-dependent, so it is advisable to process at least some background samples $(>80 \mathrm{ka})$ of the same species and provenance when measuring older samples $(>30 \mathrm{ka})$ (Nadeau et al. 2001). Where speleothem material $>>50 \mathrm{ka}$ is available from the same sample or cave setting, one can use this to reproduce typical analytical blanks, but we recognize that some material may be susceptible to postdepositional alteration because of higher porosity. In addition, sample preparation needs to be considered carefully for all material to reduce analytical blanks. For example, Beck et al. (2001) observed that powdered calcite samples drilled from some stalagmites had consistently higher ${ }^{14} \mathrm{C}$ concentrations than wafers of the same age material, and this could only be explained by difference in surface area and resultant adsorption of modern ${ }^{14} \mathrm{C}$ prior to analysis.

The ${ }^{14} \mathrm{C}$ community has devoted considerable care and effort to establishing and maintaining primary standards and reference materials and in the routine organization of laboratory intercomparisons or proficiency trials to verify comparability of measurements. From such a series of collaborative trials, secondary standards or reference materials have been developed, including internationally recognized materials such as ANU sucrose (also known as IAEA-C6), Chinese sucrose, and the IAEA C1-C6 series (Rozanski et al. 1992), augmented by additional oxalic acid samples (now IAEA C7 and C8) (Le Clercq et al. 1998). The activity of these materials has been estimated from large numbers of measurements made by many laboratories. Further natural materials from the Third and Fourth International Radiocarbon intercomparisons TIRI (Gulliksen and Scott 1995) and FIRI (Bryant et al. 2001; Scott 2003), and now VIRI (Scott et al. 2010a) have been added to this list. These standards and reference materials span both the applied ${ }^{14} \mathrm{C}$ age range and the chemical and biological composition range of typical samples. A summary of the intercomparisons organized within the ${ }^{14} \mathrm{C}$ dating community can be found in Scott (2003) and Scott et al. (2010a). The results from the most recent intercomparisons have indicated that laboratories are in general providing accurate results, but have pointed to variation in the results beyond that 
described by the quoted errors. This provides some evidence that the quoted errors are, on occasion, overestimates of the precision for some laboratories.

Recently, the ${ }^{14} \mathrm{C}$ community completed the Fifth International Intercomparison (VIRI), continuing the tradition of the TIRI (third) and FIRI (fourth) intercomparisons as a ${ }^{14} \mathrm{C}$ community project, with samples provided by participants and a substantial participation rate. VIRI was designed to have 3 stages, spread over several years, involving 2 sets of specific sample types (grain and bone) and then a final stage involving a wide variety of common sample materials. Reports on each stage have been published (Scott et al. 2010b). A new intercomparison (SIRI) is planned for 2013 and includes a set of single tree-ring samples, thus addressing directly some of the IntCal issues.

Publications presenting calibration data sets should include data from relevant intercomparison exercises, present results from other known-age samples, or provide evidence of reproducibility with existing calibration data sets.

\section{${ }^{14} \mathrm{C}$ Errors and Uncertainties}

The importance of uncertainties relating to counting statistics and those that arise by other means need to be considered separately for each data set and laboratory. However the uncertainties arise, it is crucial to state explicitly what sources have been accounted for and precisely how they have been quantified, and how background and standard errors were derived. The procedures followed in background subtraction and normalization to the standard need to be reported in detail. For clarity, laboratory error multipliers or additional variance should not be included in the reported error but reported separately. A review of the sources of uncertainty in decay counting and accelerator mass spectrometry (AMS) is given below.

\section{Decay Counting Uncertainties}

In traditional decay counting of ${ }^{14} \mathrm{C}$ (using proportional counters or liquid scintillation), samples were measured to the desired counting statistics and compared with the counting results for a standard and a background (blank). In gas proportional counting, backgrounds and standards were used over a prolonged time (from a few months to a year or so) and measured many times. This resulted in a very low statistical uncertainty in the mean values, which were used by some laboratories in the corrections for all samples analyzed in that period. In other laboratories, the population standard deviation was used, which correctly indicates the uncertainty in background, but overestimates the uncertainty in net standard and sample values when systematic fluctuations, such as seasonality and atmospheric pressure, affected blank, standard, and sample measurements. Likewise for liquid scintillation counting, the backgrounds were generally used for a period of 6 months or so and standards for a year or more. However, for calibration samples, 2 or 3 background and standard vials were measured along with the samples over a period of 2-3 months and generally the mean and uncertainty of those measurements were used for the sample age corrections. As background values were generally high for both methods (several percent of recent count values), subtraction of the (mean) background from the measured sample value resulted (for older samples with small sample activities) in relatively large uncertainties, determined by combination of the sample, standard, and background uncertainties. This is the most basic "raw" error and derives from purely Poisson counting statistics, but it is conventionally modeled as Gaussian distributed in all statistical modeling.

Further uncertainties exist that are, unfortunately, less predictable and do not (typically) obey Poisson statistics. Subtraction of a background measurement corrects for the laboratory contamination in sample pretreatment, combustion, benzene synthesis, etc. The question of whether this specific 
blank preparation was representative introduces a further uncertainty. Background corrections to gas counters for atmospheric pressure, season, or slow decay of counter walls likewise are non-Poisson, as are corrections for quenching and cosmic-ray related effects in liquid scintillation. Efficiency and cleanliness of sample preparation chemistry added another non-Poisson variability. The effect of these sources of variability can be quantified from the scatter of many repeated preparations and measurements. Assuming a Gaussian distribution of these could give an effective overall standard deviation to be compared with the Poisson count-derived standard deviation described above and a laboratory error multiplier or additional variance could then be calculated.

\section{AMS Uncertainties}

For AMS measurements, there are some essential differences but also similarities to decay counting. Despite the different physics involved (radiometry versus mass spectrometry), both follow a Poisson distribution (Vogel et al. 2004). Laboratory contamination during sample and target preparation is important for AMS, just as for decay counting. The small sample size allows for an optimal selection of sample material, but makes the result sensitive to even very small amounts of contamination. The other difference lies in the way samples are measured. In each AMS sample wheel or cassette, freshly prepared standard and background targets are measured. Thus, the statistical uncertainty in standard and background is determined within the batch and by how many standards or blanks can be used for the direct comparison with the results of the sample target. On the other hand, the machine background (counts originating from the AMS system itself) is for most systems very low, of the order of $0.2 \%$ down to $0.01 \%$ of "recent count." Thus, blank values are mostly determined by contamination inherent to the sample material and its processing. Their variability is non-Poisson and is generally estimated from the population standard deviation of a series of measurements as about one-third of the measured value of the background (independent of, and for older samples much larger than, the statistical counting error). For tightly controlled series, this may drop to onesixth of the value. Not all AMS laboratories include this empirical, blank uncertainty in their reporting, but this should be considered an essential criterion for calibration data, especially for data sets that are approaching the blank limit.

An additional source of variability in AMS measurements is related to the stability of the AMS system and the homogeneity of the sample target. In some laboratories, this is termed "machine random error" or just "random error" and refers to all sources of error that are not related to counting statistics. If only counting statistics are considered, the reported AMS uncertainty might be (significantly) underestimated. Unless this scatter is accounted for in other ways, the actual variability should be reported. Several AMS laboratories divide the measurement of a target into several intervals and compare the scatter of the interval results (the actual variability) with that predicted for those intervals from counting statistics alone. For homogeneous targets in a stable AMS system, scatter and Poisson statistics agree. If the scatter is significantly larger, it indicates system or target troubles and the larger value should be used. Other laboratories derive an estimate of the machine random error using the total variance minus the variance expected from counting statistics for the suite of standards present in every wheel of targets. Since the standards usually have high ${ }^{14} \mathrm{C} /{ }^{12} \mathrm{C}$ ratios, the counting statistic uncertainty is usually small and well determined, allowing for a good estimation of the other uncertainty terms using this method. Some of these laboratories use the long-term average of this difference to derive an estimate of machine random error.

\section{Additional Sources of Uncertainty Associated with Correction for Reservoir Effects}

A critical component of uncertainty in any estimate of ${ }^{14} \mathrm{C} /{ }^{12} \mathrm{C}$ of atmospheric or mixed layer surface ocean derived from corals, forams, and speleothems is that associated with the reservoir age (R) or 
dead carbon fraction (DCF), both of which are expected to vary with changing ocean-atmosphere reorganization and associated environmental change. In terms of selection of suitable data, there must be justification for the limited variation in R or DCF and assessment of the offset and uncertainty. Assessing the variation in these parameters is challenging and, currently, the most robust method is to compare data with the tree-ring portion of the calibration curve. While preliminary attempts have been made to assess the variation in R and DCF for individual data sets beyond the IntCal13 tree-ring data by comparison with Suigetsu data (Bronk Ramsey et al. 2012), it is accepted this should be a prime focus for research by the IntCal Working Group prior to future estimates of the calibration curves. For IntCal13, a constant regional value of $\mathrm{R}$ was used for each coral or foram data set, but the uncertainty in R used for marine data depends on the calendar age (see Reimer et al. 2013, this issue): For material $<13.9$ cal kBP, an uncertainty of $\pm 100{ }^{14} \mathrm{C}$ yr was applied, whereas for older corals $\pm 200{ }^{14} \mathrm{C}$ yr was used on the basis that $\mathrm{R}$ values are likely to be more variable during the last glacial period. It is expected that more scrutiny of reservoir age variability, backed up by modeling evidence (e.g. Butzin et al. 2005; Singarayer et al. 2008; Matsumoto and Yokayama 2013), will allow for the variation of R in forthcoming work by the IntCal Working Group.

Likewise, speleothems are expected to show variation in DCF as a function of vadose zone hydrology and geochemistry under changing environmental conditions (Hendy 1971; Genty et al. 2001; Fohlmeister et al. 2011; Rudzka et al. 2011; Griffiths et al. 2012). Different samples in the same cave system can have significantly different DCF values dependent on flow paths and drip rates amongst other factors, and they would also be expected to respond to perturbations in a variety of ways, be it dampened, lagged, threshold, or constant. Some of this variation must be accommodated in the DCF-corrected ${ }^{14} \mathrm{C}$ ages used in construction of the calibration curves, and is considered to be that remaining after subtracting the standard deviation of the mean difference between the ${ }^{14} \mathrm{C}$ age and IntCal13 tree-ring ${ }^{14} \mathrm{C}$ age at each calendar age interval. For convenience, this is considered to approximate a normal distribution.

\section{METHODS}

\section{Timescales and Uncertainties}

\section{Dendrochronology}

The use of tree-ring patterns to establish absolute ages was pioneered by A E Douglas working with conifers in the southwest United States and later in central Europe by B Huber on oak (Becker 1992). Since that time, a number of long tree-ring chronologies have been established, including the bristlecone pine chronology (Ferguson 1969; Ferguson and Graybill 1983), which was used to demonstrate the long-term variations in atmospheric ${ }^{14} \mathrm{C}$ (Suess 1970) and provide essential samples for ${ }^{14} \mathrm{C}$ measurements used in calibration curves through the 1980s and early 1990s (Klein et al. 1982; Stuiver et al. 1986; Stuiver and Reimer 1993). In Europe, subfossil preserved oak trees from bogs and river gravels were used by different research groups to construct independent long oak chronologies from different regions; those from Ireland (Pilcher et al. 1984) and Germany (Becker and Kromer 1993; Schmidt and Schwabedissen 1982; Leuschner and Delorme 1988; Friedrich et al. 2004) have been used for ${ }^{14} \mathrm{C}$ calibration. In this way, the European oak chronologies have been independently validated back to 9741 BP (7792 BC) (Pilcher et al. 1984; Spurk et al. 1998). The oldest part of the absolutely dated tree-ring chronology is formed by the southern German oak back to $10,430 \mathrm{BP}(8481 \mathrm{BC})$ and the Holocene oak is extended back to $12,560 \mathrm{BP}(10,611 \mathrm{BC})$ by the Preboreal and Younger Dryas pine chronologies from southern Germany and Switzerland, which 
have been linked dendrochronologically to the German oak (Friedrich et al. 1999, 2004; Hua et al. 2009). The Irish oak and German oak and pine chronologies provide the main body of the sample material for the IntCal09 tree-ring-based calibration curve along with trees from the west coast of North America (Reimer et al. 2009). Two independent floating chronologies (Swiss and German) from the late glacial, which have been cross-matched to each other (Hua et al. 2009; Kaiser et al. 2012), have been anchored by a ${ }^{14} \mathrm{C}$ wiggle-match to these absolute chronologies (Friedrich et al. 2004; Kromer et al. 2004; Schaub et al. 2008) and are included in the IntCal13 calibration curve (Reimer et al. 2013, this issue).

Different tree-ring laboratories have used slightly different methods to test the statistical significance of cross-correlation of a tree-ring series to the master chronology, but Pearson's correlation coefficient combined with a Student's $t$ test (Baillie et al. 1983) and coefficients of parallel variation (percent of agreement; Gleichläugkeit: GLK) (Huber 1952; Eckstein and Bauch 1969) have been most commonly used. As statistics may provide more than one probable match, the ultimate decision of a cross-match is based on the visual comparison of the series, which relies on the experience of the dendrochronologist. For example, for the construction of the Belfast Irish oak chronology, only matches that were (i) visually acceptable and (ii) produced $t$ values well in excess of 3.5 were accepted. Even then, a match suggested by the dendrochronologist and not backed up by replicated correlation values would be considered suspect (Baillie 1982; Munro 1984). This conservative approach limited the problems associated with the construction of the long Irish treering chronology. Likewise, for the European late-glacial chronologies the following cross-dating standards have been maintained: $t$ values $\geq 4.0$; GLK $\geq 60 \%$; and an acceptable visual linkage (Kaiser et al. 2012). For the construction of chronologies, critical links, and extensions of existing chronologies, the basal series must be overlapped by $\geq 100$ rings to avoid random coincidence. The homogeneity and strength of a chronology is best shown using the mean interseries correlation (RBAR) and the expressed population signal (EPS) (Wigley et al. 1984), which give a measure of the common variance of the single series that was incorporated. EPS should exceed the commonly used threshold of 0.85 for the entire length of the chronology for a satisfactory chronology signal. The crucial proof of an absolutely dated dendrochronology is the external validation by significant cross-dating of independently established tree-ring chronologies, as could be shown for the European oak chronologies (Pilcher et al. 1984; Spurk et al. 1998) and for the late-glacial pine chronologies from Switzerland and Germany (Kaiser et al. 2012). Whenever independent chronologies exist, intercomparisons are requested as a crucial and independent validation of the timescales when using the chronologies as a source of ${ }^{14} \mathrm{C}$ calibration samples. If direct comparisons of ring-width series from different regions are not feasible, because a common signal is not expected, ${ }^{14} \mathrm{C}$ "wiggle-matching" on series of ${ }^{14} \mathrm{C}$ data from the chronologies may be an adequate method to compare and verify the timescales (e.g. Linick et al. 1985).

In general, whatever method is used for building chronologies or correlating samples to a master chronology, it is imperative for calibration curve samples that the dendrochronology is well established and fully published. Publication should include details of the methodology used for tree-ring analysis, full details of the cross-matching and cross-dating of each tree-ring series, the remaining uncertainty in the absolute ages, and should cite the version of the chronology used for dating. Raw tree-ring widths of trees sampled for calibration data should be published or logged in a digital archive. Publication of calibration data sets should make clear exactly which rings from which individual tree-ring series were included in each ${ }^{14} \mathrm{C}$ sample. Whenever possible, pooling of synchronous tree rings of different trees in one ${ }^{14} \mathrm{C}$ sample should be avoided and samples of single trees should be kept separate. 


\section{Uranium-Thorium Dating}

U-Th dating provides absolute ages for corals and speleothem samples used to construct calibration records. Many of the criteria presented for coral U-Th measurement in Reimer et al. (2002) are applicable to speleothems as well and are summarized below. In general, U-Th age uncertainty is quoted at the $2 \sigma$ level. We note, with caution, that this differs from standard practice in ${ }^{14} \mathrm{C}$ and $\mathrm{Ar}-$ Ar dating and can cause confusion: All data in the IntCal13 database is quoted as $1 \sigma$. Combined uncertainty includes that associated with all aspects of measurement and derivation, including corrections for analytical blank, decay constants, and internal error. Full documentation of mass-spectrometric protocols should be given, providing details about the calibration of $U$ and Th spikes used to quantify isotopic ratios.

Typically, internal and external reproducibility and accuracy should be demonstrated using standards with well-known isotopic ratios, such as NIST-supplied certified reference materials (112A and 145 ) for ${ }^{234} U / 238 U$. There are no traceable community standards for U-Th ratios and laboratories must rely on in-house standards, perhaps derived from uraninite solutions (e.g. Harwell uraninite) or gravimetrically determined mixed U-Th standards. Also, replicates of different parts of the same sample should be measured as often as possible to derive an estimate of external reproducibility for U-Th ages and $\delta^{234} \mathrm{U}_{\text {initial }}$. Durand et al. (2013, this issue) detail efforts to demonstrate consistent results in more than one laboratory.

There have been successful intercomparison efforts among the community involved in PALSEA efforts (Bill Thompson, personal communication). There is strong motivation for more comprehensive comparison, along the lines of the FIRI to VIRI efforts in ${ }^{14} \mathrm{C}$ (Bryant et al. 2001; Scott 2003; Scott et al. 2010a,b). More widespread intercomparison is likely to follow the imminent distribution of synthetic age solutions among the U-Th community as part of a UK NERC-funded project ("Sharpening the U-Th Chronometer," 2011-2014) that is based on the U-Pb Earthtime initiative (McLean et al. 2008).

The half-lives used for ${ }^{238} \mathrm{U},{ }^{234} \mathrm{U}$, and ${ }^{230} \mathrm{Th}$ must always be quoted. The half-lives of ${ }^{234} \mathrm{U}$ and ${ }^{230} \mathrm{Th}$ were revised by Cheng et al. (2000) and these values were adopted for all U-Th data in IntCal13. New estimates have recently been published by Cheng et al. (2013) with reduced uncertainties and it is likely that there will be amendments in the future. ${ }^{232} \mathrm{Th}$ concentration of fossil corals should exhibit low values (e.g. less than a few parts per billion) indicating a negligible amount of associated detrital and/or scavenged ${ }^{230} \mathrm{Th}$.

Pa-U ages may be useful to check for concordance with U-Th ages measured on samples suspected to be altered by exposure to freshwater (vadose zone and uplifted terraces). However, a systematic survey demonstrating that this criterion allows better screening of corals that remained below seawater has not been published.

Much of the above applies to U-Th ages derived for calcite from stalagmite, stalactites, and flowstones, but there are additional factors that can affect the overall uncertainty of the calendar age associated with each ${ }^{14} \mathrm{C}$ age determination in speleothems. Growth rate and sample size is important. In contrast to corals, where sufficient material can be obtained from subannual bands, many years of growth are sampled in speleothems to provide sufficient material for analysis. The morphology and growth rate of a sample must be taken in to account if the associated ${ }^{14} \mathrm{C}$ determination is not analyzed on exactly the same subsample or interpolation is involved (see section "Age-Depth Models"). With increasing precision and smaller sample sizes, it has been noted that in some settings there can be elevated concentrations of initial ${ }^{230} \mathrm{Th}$ in speleothems. The initial ${ }^{230} \mathrm{Th} /{ }^{232} \mathrm{Th}$ 
ratio should be assessed routinely and, if values significantly different from Bulk Earth values are apparent for individual growth layers, one would expect to see an estimation of within sample variability (e.g. Beck et al. 2001; Carolin et al. 2013). Where ${ }^{232} \mathrm{Th}$ concentrations are very low, corrections are negligible, but it is expected that some assessment of potential variation of initial ${ }^{230} \mathrm{Th} /$ ${ }^{232} \mathrm{Th}$ ratio is made by isochron analysis (Richards and Dorale 2003).

\section{Varve Counting}

Sedimentation in any lacustrine or marine archive is sensitive to changes in the prevailing conditions. This is true on all timescales, from individual events lasting days through to millennial length changes in climate. Where the seasonal signal is strong enough, it is possible for varves to form by a number of different processes (clastic, biogenic, chemical). Their survival in the sediment record is normally prevented by bioturbation or other disturbances and as a result they usually only form in anoxic and sheltered conditions. These varves then provide us with a method for relative dating entirely analogous to ice-core layers or tree rings (Lamoureux 2001; Zolitschka 2003; Brauer 2004; Ojala et al. 2012).

Although varves have the potential to provide timescales for calibration purposes, there are a number of issues that need to be considered when using them. The most obvious is that varves are only a relative dating technique, and rarely extend right up to the present in archives that might be used for calibration. It is therefore essential that varved archives used for ${ }^{14} \mathrm{C}$ dating are linked in some way to another chronology which itself fulfils the requirements for calibration (typically dendrochronology or U-Th dating). More difficult to deal with is the fact that varves are rarely truly reliable chronometers; there is almost always some ambiguity when assessing the annual cycle and both missing varves and double counting of years due to extreme events are possible problems. For this reason, 3 criteria must be met in the application of varved chronologies: firstly, the varves must be studied, at least in part, by thin section in order to understand their nature and to check for possible changes in sedimentation such as hiatuses and event layers; secondly, the varves should be counted by more than one person (Ojala et al. 2012) and ideally by more than one method; finally, some assessment of the uncertainty in the varve count should be made, both in terms of relative errors and cumulative uncertainty.

In practice, cumulative uncertainties in varve chronologies may be on the order of 1-2\% (Hughen et al. 1998) but increase for the older portion of very long records such as Lake Suigetsu (Bronk Ramsey et al. 2012). For this reason, it will usually be necessary, not only to have a single tie-point for such a chronology but also constraints from, or checks against, other chronologies (which fit the calibration criteria) to check for long-term drift and identify any significant anomalies that might not be apparent in the sediment itself. Control points to other chronologies should ideally be based on physical mechanisms that provide true synchrony (such as tephra or cosmogenic isotope signals). Where climatic correlations are used, the basis for assuming synchrony and the uncertainties in such synchrony need to be made clear.

\section{Wiggle-Matching}

Wiggle-matching is used to anchor a "floating" (relative) chronology with known spacing between determinations to another record for which an absolute chronology is available. A floating sequence of ${ }^{14} \mathrm{C}$ determinations is typically anchored by matching the ${ }^{14} \mathrm{C}$ variations in the floating record to those in one that already has an independently derived absolute chronology. This can be done either using a classical best-fit approach (Pearson 1986) or a Bayesian method (Christen and Litton 1995; Bronk Ramsey et al. 2001). The uncertainty induced by undertaking the wiggle-match is shared by 
all of the data points in the floating sequence and thus must carefully be articulated so that the dependence that is induced between them can be properly accounted for in comparisons with other data sets. This uncertainty must be recorded separately from any other sources of error affecting those points.

\section{Age-Depth Models}

For some archives, such as speleothems, the sampling intervals for ${ }^{14} \mathrm{C}$ age and calendar age measurements may be at different depths within the sequence. This results in the need for an age-depth model to provide the necessary chronological information at the depths where the ${ }^{14} \mathrm{C}$ measurements were made. Any age-depth model should be implemented in such a way that the data providers can offer not just a statement of the most likely chronology, but can clearly articulate the nature, scale, and structure of all associated uncertainties. Typically, such modeling will induce dependence between the errors on different ages; in such cases, the matrix of covariances between them (or sufficient information to reconstruct it) should be made available.

\section{Tie-Pointed Timescales ("Tuning")}

Tie-pointed timescales are based on the following assumptions:

1. The climate proxies in both the independently dated master record and the data set to be tiepointed to it record the same events with approximately the same relative magnitudes. In some cases, a particular series of climatic events may be recognized, such as interstadials in which a strong signal precedes 3 small signals (e.g. Bond et al. 1993);

2. Key climatic events, such as abrupt (decadal) transitions into stadials and interstadials, are recorded in both the master and "tuned" records within a known or estimated lead or lag. This may need to be established with independent evidence (e.g. tephra layers within Younger Dryas sediments) or from a different period with independent chronologies (e.g. varved sediments in the Cariaco Basin during the deglaciation but not during earlier stadial events; Hughen et al. 1996, 2004).

If such assumptions hold, then suitable climatic changes and events should be recognizable in all targeted ice cores, speleothems, and marine records with sufficient resolution and preferably multiple proxy measurements.

It is essential that the paleoclimatological or paleoceanographical signal of the proxies' response to climate changes is thoroughly understood and documented (i.e. in refereed publications). The reasons for assuming synchronicity, including any leads or lags, and a solid assertion of the physical mechanism allowing the climatic signal to be expressed in both the master and tuned record must be published in an international, peer-reviewed journal. It must be clear which master climate record and timescale were used and also how tie-points were selected and ages between tie-points were modeled. The relationship between climate and growth/accumulation rate should be taken into account, and suitable tie-points selected to avoid artifacts from accumulation rate changes. We recommend that several different proxies are measured in the archive being tuned in order to check correlation with the master record (cf. Bard et al. 2004, 2013, this issue). As with speleothem agedepth models, the uncertainty of a calendar age in the tie-pointed record is not independent. A covariance matrix to fully account for this dependency should be provided (cf. Heaton et al. 2013, this issue). 


\section{Data and Metadata Requirements}

Every calibration data set should include the metadata (Table 1) and sample-specific information (Table 2). Additionally, a covariance matrix may be attached to the data record (see section "TiePointed Timescales").

Table 1 Metadata requirements for the IntCal database.

\begin{tabular}{|c|c|}
\hline Metadata name & Example \\
\hline Location of archive & Lat/Lon, name of location \\
\hline Method of ${ }^{14} \mathrm{C}$ measurement & LSC, GPS, or AMS \\
\hline Archive code or name (e.g. core ID, tree name) & e.g. PL07-58PC \\
\hline $\begin{array}{l}\text { Laboratory uncertainties reported in }{ }^{14} \mathrm{C} \text { error } \\
\text { fields in the data table (note that any laboratory er- } \\
\text { ror multiplier or extra additive error should be re- } \\
\text { ported separately from the basic measurement } \\
\text { error) }\end{array}$ & $\begin{array}{l}\text { Long-term background variability (e.g. } \\
\text { sigma background = } 1 / 3 \text { measured back- } \\
\text { ground), long-term standard variability, lab } \\
\text { error multiplier, and/or extra additive error }\end{array}$ \\
\hline $\begin{array}{l}\text { Detailed sample preparation and pretreatment } \\
\text { prior to }{ }^{14} \mathrm{C} \text { measurement }\end{array}$ & $\begin{array}{l}\text { Physical: e.g. powdered, ground, or taken } \\
\text { as a slice or wafer } \\
\text { chemical: e.g. alpha-cellulose, ABA, acid- } \\
\text { etched (leaching), drying and operating } \\
\text { temperature, preservation conditions, acid/ } \\
\text { alkali concentration, solvent mixture, inert } \\
\text { atmosphere, with references if appropriate }\end{array}$ \\
\hline \multicolumn{2}{|l|}{$\begin{array}{l}\text { Detailed sample preparation and pretreatment } \\
\text { prior to cal age measurement and estimation }\end{array}$} \\
\hline $\begin{array}{l}\text { Methods used to estimate cal age uncertainties re- } \\
\text { ported in the data table }\end{array}$ & \\
\hline
\end{tabular}

Table 2 Data requirements for the IntCal database.

\begin{tabular}{|c|c|}
\hline Data item name & Example \\
\hline${ }^{14} \mathrm{C}$ laboratory ID & e.g. QL-12164 \\
\hline \multicolumn{2}{|l|}{ cal age BP } \\
\hline cal age span & Number of tree rings in sample, etc. \\
\hline Dependent cal age uncertainty & Wiggle-match uncertainty \\
\hline Independent cal age uncertainty & Uranium-thorium uncertainty \\
\hline Cumulative cal age uncertainty & Cumulative varve count uncertainty \\
\hline \multicolumn{2}{|l|}{${ }^{14} \mathrm{C}$ age $\mathrm{BP}$} \\
\hline${ }^{14} \mathrm{C}$ error ( 1 s.d.) & $\begin{array}{l}\text { Reported measurement error including errors } \\
\text { in blanks, standards }\end{array}$ \\
\hline $\begin{array}{l}{ }^{14} \mathrm{C} \text { error multiplier, if applicable (a positive } \\
\text { value to be used to scale the reported measure- } \\
\text { ment error, typically on a collection of related } \\
\text { samples, via multiplication) }\end{array}$ & $\begin{array}{l}\text { Derived from replicate analysis of samples } \\
\text { or secondary standards or comparison to ex- } \\
\text { isting data (such as done for tree rings in } \\
\text { IntCal04, IntCal09) }\end{array}$ \\
\hline $\begin{array}{l}{ }^{14} \mathrm{C} \text { additive error, if applicable (a positive value } \\
\text { to be used to increase the reported uncertainty } \\
\text { via addition in quadrature) }\end{array}$ & $\begin{array}{l}\text { Additional uncertainty not included in an er- } \\
\text { ror multiplier (e.g. sample processing uncer- } \\
\text { tainty) }\end{array}$ \\
\hline Reservoir offset & $\begin{array}{l}\text { Marine reservoir age offset or dead carbon } \\
\text { fraction offset in speleothems }\end{array}$ \\
\hline Reservoir offset uncertainty & Estimate of uncertainty in the reservoir offset \\
\hline
\end{tabular}




\section{DISCUSSION AND CONCLUSION}

In summary, steps should be taken at every stage of sample selection, pretreatment, and measurement to ensure transparency for the generation of high-quality data sets (including careful articulation and quantification of uncertainties). The quantification and classification of errors in both the ${ }^{14} \mathrm{C}$ and the absolute timescale are of utmost importance. This article outlines a range of archives that may provide useful data sets for ${ }^{14} \mathrm{C}$ calibration. All of these have strengths and limitations, and we propose criteria relevant to each record that we believe will maximize its utility for accurate ${ }^{14} \mathrm{C}$ calibration. Science is, however, never static and, just as calibration curves are always works in progress, so must be the criteria for the inclusion of data sets in any "consensus" ${ }^{14} \mathrm{C}$ calibration curves. Beneath the detailed criteria proposed for each archive are common principles; that data should be published in as much detail as possible and that all sources of uncertainty should be explored as rigorously as possible. Calibration data have a wide significance and application beyond the discipline and the time in which they were created. It is essential that these data sets are published in sufficient detail to allow future generations of researchers to re-examine them in the light of new scientific understanding as this emerges.

With this in mind, we invite colleagues who have data sets that they feel meet the criteria outlined in this paper to contact a member of the IWG with a view to their inclusion in the next update of the IntCal curves. We also invite comments and suggestions on how the criteria outlined in this paper, and the calibration curves based on them, might be improved.

\section{ACKNOWLEDGMENTS}

The IntCal Working Group network was initially funded by the Leverhulme Trust. Funding for this work was provided in part by the Natural Environment Research Council, UK grant NE/I01666X/1 and NE/E019129/1 and the US National Science Foundation supported contributions by some of the coauthors. Travel expenses for two members of the IntCal Oversight Committee to attend working group meetings were funded by the IGBP - PAGES (International Geosphere-Biosphere Programme - Past Global Changes) Project. Additional support for the Working Group meetings was provided by the Collège de France, the ${ }^{14} \mathrm{CHRONO}$ Centre, QUB, and by individual members. The authors wish to thank Achim Brauer for his constructive review.

\section{REFERENCES}

Abbott MB, Stafford Jr TW. 1996. Radiocarbon geochemistry of modern and ancient arctic lake systems, Baffin Island, Canada. Quaternary Research 45(3):300-11.

Andersson AJ, Mackenzie FT. 2011. Technical comment on Kroeker et al. (2010) Meta-analysis reveals negative yet variable effects of ocean acidification on marine organisms. Ecology Letters, 13, 1419-1434. Ecology Letters 14(8):E1-E2.

Andersson AJ, Mackenzie FT, Bates NR. 2008. Life on the margin: implications of ocean acidification on $\mathrm{Mg}$ calcite, high latitude and cold-water marine calcifiers. Marine Ecology Progress Series 373:265-73.

Ascough PL, Bird MI, Brock F, Higham TFG, Meredith W, Snape CE, Vane CH. 2009. Hydropyrolysis as a new tool for radiocarbon pre-treatment and the quantification of black carbon. Quaternary Geochronology 4(2):140-7.
Austin WEN, Bard E, Hunt JB, Kroon D, Peacock JD. 1995. The ${ }^{14} \mathrm{C}$ age of the Icelandic Vedde Ash: implications for Younger Dryas marine reservoir age corrections. Radiocarbon 37(1):53-62.

Austin WEN, Telford RJ, Ninnemann US, Brown L, Wilson LJ, Small DP, Bryant CL. 2011. North Atlantic reservoir ages linked to high Younger Dryas atmospheric radiocarbon concentrations. Global and Planetary Change 79(3-4):226-33.

Baillie MGL. 1982. Tree-Ring Dating and Archaeology. London: Croom Helm. 274 p.

Baillie MGL, Pilcher JR, Pearson GW. 1983. Dendrochronology at Belfast as a background to high-precision calibration. Radiocarbon 25(2):171-8.

Baldini JUL. 2010. Cave atmosphere controls on stalagmite growth rate and palaeoclimate records. In: Pedley HM, Rogerson M, editors. Tufas and Speleothems: Unravelling the Microbial and Physical Controls. 
London: London Geological Society. p 283-94.

Bard E. 1988. Correction of accelerator mass spectrometry ${ }^{14} \mathrm{C}$ ages measured in planktonic foraminifera: paleoceanographic implications. Paleoceanography 3(6):635-45.

Bard E, Arnold M, Duprat J, Moyes J, Duplessy J-C. 1987. Reconstruction of the last deglaciation: deconvolved records of $\delta^{18} \mathrm{O}$ profiles, micropaleontological variations and accelerator mass spectrometric ${ }^{14} \mathrm{C}$ dating. Climate Dynamics 1(2):101-12.

Bard E, Hamelin B, Fairbanks RG, Zindler A. 1990a. Calibration of the ${ }^{14} \mathrm{C}$ timescale over the past 30,000 years using mass spectrometric U-Th ages from Barbados corals. Nature 345(6274):405-10.

Bard E, Hamelin B, Fairbanks RG, Zindler A, Mathieu G, Arnold M. 1990b. U/Th and ${ }^{14} \mathrm{C}$ ages of corals from Barbados and their use for calibrating the ${ }^{14} \mathrm{C}$ time scale beyond 9000 years B.P. Nuclear Instruments and Methods in Physics Research B 52(3-4):461-8.

Bard E, Arnold M, Mangerud J, Paterne M, Labeyrie L, Duprat J, Mélières MA, Sønstegaard E, Duplessy J-C. 1994. The North Atlantic atmosphere-sea surface ${ }^{14} \mathrm{C}$ gradient during the Younger Dryas climatic event. Earth and Planetary Science Letters 126(4):275-87.

Bard E, Menot-Combes G, Rostek F. 2004. Present status of radiocarbon calibration and comparison records based on Polynesian corals and Iberian Margin sediments. Radiocarbon 46(3):1189-202.

Bard E, Ménot G, Rostek F, Licari L, Böning P, Edwards RL, Cheng H, Wang YJ, Heaton TJ. 2013. Radiocarbon calibration/comparison records based on marine sediments from the Pakistan and Iberian margins. $R a-$ diocarbon 55(4), this issue.

Barker S, Broecker W, Clark E, Hajdas I. 2007. Radiocarbon age offsets of foraminifera resulting from differential dissolution and fragmentation within the sedimentary bioturbated zone. Paleoceanography 22: PA2205, doi:10.1029/2006PA001354.

Barnekow L, Possnert G, Sandgren P. 1998. AMS ${ }^{14} \mathrm{C}$ chronologies of Holocene lake sediments in the Abisko area, northern Sweden - a comparison between dated bulk sediment and macrofossil samples. GFF 120(1):59-67.

Beck JW, Richards DA, Edwards RL, Silverman BW, Smart PL, Donahue DJ, Hererra-Osterheld S, Burr GS, Calsoyas L, Jull AJT, Biddulph D. 2001. Extremely large variations of atmospheric ${ }^{14} \mathrm{C}$ concentration during the last glacial period. Science 292(5526): 2453-8.

Becker B. 1992. The history of dendrochronology and radiocarbon calibration. In: Taylor RE, Long A, Kra RS, editors. Radiocarbon After Four Decades. New York: Springer. p 34-49.

Becker B, Kromer B. 1993. The continental tree-ring record - absolute chronology, ${ }^{14} \mathrm{C}$ calibration and climatic change at $11 \mathrm{ka}$. Palaeogeography, Palaeoclimatology, Palaeoecology 103(1-2):67-71.
Blackwell PG, Buck CE. 2008. Estimating radiocarbon calibration curves. Bayesian Analysis 3(2):225-48.

Bond G, Broecker W, Johnsen S, McManus J, Labeyrie L, Jouzel J, Bonani G. 1993. Correlations between climate records from North Atlantic sediments and Greenland ice. Nature 365(6442):143-7.

Bondevik S, Mangerud J, Birks HH, Gulliksen S, Reimer P. 2006. Changes in North Atlantic radiocarbon reservoir ages during the Allerød and Younger Dryas. Science 312(5779): 1514-7.

Boston HL. 1986. A discussion of the adaptations for carbon acquisition in relation to the growth strategy of aquatic isoetids. Aquatic Botany 26:259-70.

Brauer A. 2004. Annually laminated lake sediments and their palaeoclimatic relevance. In: Fischer H, Kumke T, Lohmann G, Flöser G, Miller H, Von Storch H, Negendank J, editors. The Climate in Historical Times. Towards a Synthesis of Holocene Proxy Data and Climate Models. Berlin: Springer. p 109-27.

Braziunas TF, Fung IY, Stuiver M. 1995. The preindustrial atmospheric ${ }^{14} \mathrm{CO}_{2}$ latitudinal gradient as related to exchanges among atmospheric, oceanic, and terrestrial reservoirs. Global Biogeochemical Cycles 9(4): 565-84.

Bronk Ramsey C, van der Plicht J, Weninger B. 2001. 'Wiggle matching' radiocarbon dates. Radiocarbon 43(2A):381-9.

Bronk Ramsey C, Staff RA, Bryant CL, Brock F, Kitagawa $\mathrm{H}$, van der Plicht J, Schlolaut G, Marshall MH, Brauer A, Lamb HF, Payne RL, Tarasov PE, Haraguchi T, Gotanda K, Yonenobu H, Yokoyama Y, Tada R, Nakagawa T. 2012. A complete terrestrial radiocarbon record for 11.2 to $52.8 \mathrm{kyr}$ B.P. Science 338(6105): $370-4$.

Bryant C, Carmi I, Cook GT, Gulliksen S, Harkness DD, Heinemeier J, McGee E, Naysmith P, Possnert G, Scott EM, van der Plicht J, Van Strydonck M. 2001. Is comparability of ${ }^{14} \mathrm{C}$ dates an issue? A status report on the Fourth International Radiocarbon Intercomparison. Radiocarbon 43(2A):321-4.

Burr GS, Edwards RL, Donahue DJ, Druffel ERM, Taylor FW. 1992. Mass-spectrometric ${ }^{14} \mathrm{C}$ and U-Th measurements in coral. Radiocarbon 34(3):611-8

Butzin M, Prange M, Lohmann G. 2005. Radiocarbon simulations for the glacial ocean: the effects of wind stress, Southern Ocean sea ice and Heinrich events. Earth and Planetary Science Letters 235(1-2):45-61.

Cain WF, Suess HE. 1976. Carbon 14 in tree rings. Journal of Geophysical Research-Oceans and Atmospheres 81(21):3688-94.

Carolin SA, Cobb KM, Adkins JF, Clark B, Conroy JL, Lejau S, Malang J, Tuen AA. 2013. Varied response of western Pacific hydrology to climate forcings over the last glacial period. Science 340(6140):1564-6.

Chappell J, Broecker WS, Polach HA, Thom BG. 1974. Problem of dating Upper Pleistocene sea levels from coral reef areas. In: Proceedings of the 2nd Interna- 
tional Coral Reef Symposium. Volume 2. Brisbane. p 561-71.

Cheng H, Edwards RL, Hoff J, Gallup CD, Richards DA, Asmeron Y. 2000. The half-lives of uranium-234 and thorium-230. Chemical Geology 169(1-2):17-33.

Cheng H, Edwards RL, Shen CC, Polyak VJ, Asmerom Y, Woodhead J, Hellstrom J, Wang YJ, Kong XG, Spötl C, Wang XF, Alexander Jr EC. 2013. Improvements in ${ }^{230} \mathrm{Th}$ dating, ${ }^{230} \mathrm{Th}$ and ${ }^{234} \mathrm{U}$ half-life values, and U-Th isotopic measurements by multi-collector inductively coupled plasma mass spectrometry. Earth and Planetary Science Letters 371-372:82-91.

Chiu T-C, Fairbanks RG, Mortlock RA, Bloom AL. 2005. Extending the radiocarbon calibration beyond 26,000 years before present using fossil corals. Quaternary Science Reviews 24(16-17):1797-808.

Christen JA, Litton CD. 1995. A Bayesian approach to wiggle-matching. Journal of Archaeological Science 22(6):719-25.

Cutler KB, Gray SC, Burr GS, Edwards RL, Taylor FW, Cabioch G, Beck JW, Cheng H, Moore J. 2004. Radiocarbon calibration and comparison to $50 \mathrm{kyr} \mathrm{BP}$ with paired ${ }^{14} \mathrm{C}$ and ${ }^{230} \mathrm{Th}$ dating of corals from Vanuatu and Papua New Guinea. Radiocarbon 46(3):1127-60.

de Vries H, Barendsen GW. 1952. A new technique for the measurement of age by radiocarbon. Physica 18: 652.

Dee MW, Brock F, Harris SA, Bronk Ramsey C, Shortland AJ, Higham TFG, Rowland JM. 2010. Investigating the likelihood of a reservoir offset in the radiocarbon record for ancient Egypt. Journal of Archaeological Science 37(4):687-93.

Douka K, Higham T, Sinitsyn A. 2010. The influence of pretreatment chemistry on the radiocarbon dating of Campanian Ignimbrite-aged charcoal from Kostenki 14 (Russia). Quaternary Research 73(3):583-7.

Druffel ERM, Robinson LF, Griffin S, Halley RB, Southon JR, Adkins JF. 2008. Low reservoir ages for the surface ocean from mid-Holocene Florida corals. $\mathrm{Pa}$ leoceanography 23: PA2209, doi:10.1029/ 2007 PA001527.

Durand N, Deschamps P, Bard E, Hamelin B, Camoin G, Thomas AL, Henderson GM, Yokoyama Y, Matsuzaki H. 2013. Comparison of ${ }^{14} \mathrm{C}$ and U-Th ages in corals from IODP \#310 cores offshore Tahiti. Radiocarbon 55(4), this issue.

Eckstein D, Bauch J. 1969. Beitrag zur Rationalisierung eines dendrochronologischen Verfahrens und zur Analyse seiner Aussagesicherheit. Forstwissenschaftliches Centralblatt 88:230-50.

Edwards RL, Beck JW, Burr GS, Donahue DJ, Chappell JMA, Bloom AL, Druffel ERM, Taylor FW. 1993. A large drop in atmospheric ${ }^{14} \mathrm{C} /{ }^{12} \mathrm{C}$ and reduced melting in the Younger Dryas, documented with ${ }^{230} \mathrm{Th}$ ages of corals. Science 260(5110):962-8.

Esat TM, Yokoyama Y. 2006. Variability in the uranium isotopic composition of the oceans over glacial-interglacial timescales. Geochimica et Cosmochimica Acta
70(16):4140-50.

Ferguson CW. 1969. A 7104-year annual tree-ring chronology for bristlecone pine, Pinus aristata, from the White Mountains, California. Tree-Ring Bulletin 29: $1-29$.

Ferguson CW, Graybill DA. 1983. Dendrochronology of bristlecone pine: a progress report. Radiocarbon 25(2):287-8.

Fohlmeister J, Kromer B, Mangini A. 2011. The influence of soil organic matter age spectrum on the reconstruction of atmospheric ${ }^{14} \mathrm{C}$ levels via stalagmites. Radiocarbon 53(1):99-115.

Franke J, Paul A, Schulz M. 2008. Modeling variations of marine reservoir ages during the last 45000 years. Climate of the Past 4:125-36.

Friedrich M, Kromer B, Spurk H, Hofmann J, Kaiser KF. 1999. Paleo-environment and radiocarbon calibration as derived from Lateglacial/Early Holocene tree-ring chronologies. Quaternary International 61(1):27-39.

Friedrich M, Remmele S, Kromer B, Hofmann J, Spurk M, Kaiser KF, Orcel C, Küppers M. 2004. The 12,460year Hohenheim oak and pine tree-ring chronology from central Europe- a unique annual record for radiocarbon calibration and paleoenvironment reconstructions. Radiocarbon 46(3):1111-22.

Genty D, Baker A, Massault M, Proctor C, Gilmour M, Pons-Branchu E, Hamelin B. 2001. Dead carbon in stalagmites: carbonate bedrock paleodissolution vs. ageing of soil organic matter. Implications for ${ }^{13} \mathrm{C}$ variations in speleothems. Geochimica et Cosmochimica Acta 65(20):3443-57.

Griffiths ML, Fohlmeister J, Drysdale RN, Hua Q, Johnson KR, Hellstrom JC, Gagan MK, Zhao JX. 2012. Hydrological control of the dead carbon fraction in a Holocene tropical speleothem. Quaternary Geochronology 14:81-93.

Grootes PM, Farwell GW, Schmidt FH, Leach DD, Stuiver M. 1989. Rapid response of tree cellulose radiocarbon content to changes in atmospheric ${ }^{14} \mathrm{CO}_{2}$ concentration. Tellus B 41(2):134-48.

Gulliksen S, Scott M. 1995. Report of the TIRI workshop, Saturday 13 August 1994. Radiocarbon 37(2): 820-1.

Haflidason H, Eiriksson J, Van Kreveld S. 2000. The tephrochronology of Iceland and the North Atlantic region during the Middle and Late Quaternary: a review. Journal of Quaternary Science 15(1):3-22.

Hajdas I, Bonani G, Zolitschka B, Brauer A, Negendank J. 1998. ${ }^{14} \mathrm{C}$ ages of terrestrial macrofossils from Lago Grande di Monticchio (Italy). Radiocarbon 40(2): 803-7.

Hatté C, Jull AJT. 2007. Radiocarbon dating: plant macrofossils. In: Elias SA, editor. Encyclopedia of Quaternary Science. Oxford: Elsevier. p 2958-65.

Hatté C, Morvan J, Noury C, Paterne M. 2001. Is classical acid-alkali-acid treatment responsible for contamination? An alternative proposition. Radiocarbon 43(2A):177-82. 
Heaton TJ, Blackwell PG, Buck CE. 2009. A Bayesian approach to the estimation of radiocarbon calibration curves: the IntCal09 methodology. Radiocarbon 51(4):1151-64.

Heaton TJ, Bard E, Hughen K. 2013. Elastic tie-pointing - transferring chronologies between records via a Gaussian process. Radiocarbon 55(4), this issue.

Heier-Nielsen S, Conradsen K, Heinemeier J, Knudsen KL, Nielsen HL, Rud N, Sveinbjörnsdóttir AE. 1995. Radiocarbon dating of shells and foraminifera from the Skagen Core, Denmark: evidence of reworking. Radiocarbon 37(2):119-30.

Hendy CH. 1971. The isotopic geochemistry of speleothems-I. the calculation of the effects of different modes of formation on the isotopic composition of speleothems and their applicability as palaeoclimatic indicators. Geochimica et Cosmochimica Acta 35(8): 801-24.

Higham T, Brock F, Peresani M, Broglio A, Wood R, Douka K. 2009. Problems with radiocarbon dating the Middle to Upper Palaeolithic transition in Italy. Quaternary Science Reviews 28(13-14):1257-67.

Hogg AG, Fifield LK, Turney CSM, Palmer JG, Galbraith R, Baillie MGL. 2006. Dating ancient wood by high sensitivity liquid scintillation counting and accelerator mass spectrometry - pushing the boundaries. Quaternary Geochronology 1(4):241-8.

Hogg A, Palmer J, Boswijk G, Reimer P, Brown D. 2009. Investigating the interhemispheric ${ }^{14} \mathrm{C}$ offset in the $1 \mathrm{st}$ millennium $\mathrm{AD}$ and assessment of laboratory bias and calibration errors. Radiocarbon 51(4):1177-86.

Hogg A, Palmer J, Boswijk G, Turney C. 2011. High-precision radiocarbon measurements of tree-ring dated wood from New Zealand: 195 BC-AD 995. Radiocarbon 53(3):529-42.

Hua Q, Barbetti M, Zoppi U, Fink D, Watanasak M, Jacobsen GE. 2004. Radiocarbon in tropical tree rings during the Little Ice Age. Nuclear Instruments and Methods in Physics Research B 223-224:489-94.

Hua Q, Barbetti M, Fink D, Kaiser KF, Friedrich M, Kromer B, Levchenko VA, Zoppi U, Smith AM, Bertuch F. 2009. Atmospheric ${ }^{14} \mathrm{C}$ variations derived from tree rings during the early Younger Dryas. Quaternary Science Reviews 28(25-26):2982-90.

Huber B. 1952. Beitraege zur Methodik der Jahrringchronologie. Gegenlaeufigkeitsprozent und Gegenlaeufigkeitsstruktur als Masstaebe bei der Sicherung jahrringchronologischer Datierungen. (Contributions to the methodology of tree-ring analysis. I. Percent and structure of disagreement as a measure of accuracy in tree-ring dating). Holzforschung - International Journal of the Biology, Chemistry, Physics and Technology of Wood 6:33-7.

Hughen KA, Overpeck JT, Peterson LC, Trumbore S. 1996. Rapid climate changes in the tropical Atlantic region during the last deglaciation. Nature 380(6569): $51-4$.

Hughen KA, Overpeck JT, Lehman SJ, Kashgarian M,
Southon JR, Peterson LC. 1998. A new ${ }^{14} \mathrm{C}$ calibration data set for the last deglaciation based on marine varves. Radiocarbon 40(1):483-94.

Hughen KA, Baillie MGL, Bard E, Beck JW, Bertrand CJH, Blackwell PG, Buck CE, Burr GS, Cutler KB, Damon PE, Edwards RL, Fairbanks RG, Friedrich M, Guilderson TP, Kromer B, McCormac G, Manning S, Bronk Ramsey C, Reimer PJ, Reimer RW, Remmele S, Southon JR, Stuiver M, Talamo S, Taylor FW, van der Plicht J, Weyhenmeyer CE. 2004. Marine04 marine radiocarbon age calibration, $0-26 \mathrm{cal}$ kyr BP. $R a-$ diocarbon 46(3):1059-86.

Hughen K, Southon J, Lehman S, Bertrand C, Turnbull J. 2006. Marine-derived ${ }^{14} \mathrm{C}$ calibration and activity record for the past 50,000 years updated from the Cariaco Basin. Quaternary Science Reviews 25(23-24): 3216-27.

Kaiser KF, Friedrich M, Miramont C, Kromer B, Sgier M, Schaub M, Boeren I, Remmele S, Talamo S, Guibal F, Sivan O. 2012. Challenging process to make the Lateglacial tree-ring chronologies from Europe absolute - an inventory. Quaternary Science Reviews 36:78-90.

Kitagawa H, van der Plicht J. 1998. A 40,000-year varve chronology from Lake Suigetsu, Japan: extension of the ${ }^{14} \mathrm{C}$ calibration curve. Radiocarbon 40(1):505-15.

Klein J, Lerman JC, Damon PE, Ralph EK. 1982. Calibration of radiocarbon-dates - tables based on the consensus data of the Workshop on Calibrating the Radiocarbon Time Scale. Radiocarbon 24(2):103-50.

Kromer B, Manning SW, Kuniholm PI, Newton MW, Spurk M, Levin I. 2001. Regional ${ }^{14} \mathrm{CO}_{2}$ gradients in the troposphere: magnitude, mechanisms and consequences. Science 294(5551):2529-32.

Kromer B, Friedrich M, Hughen KA, Kaiser F, Remmele S, Schaub M, Talamo S. 2004. Late glacial ${ }^{14} \mathrm{C}$ ages from a floating, 1382-ring pine chronology. Radiocarbon 46(3):1203-9.

Lamoureux SF. 2001. Varve chronology techniques. In: Last WM, Smol JP, editors. Developments in Paleoenvironmental Research (DPER), Tracking Environmental Change Using Lake Sediments. Dordrecht: Kluwer. p 247-60.

Le Clercq M, van der Plicht J, Gröning M. 1998. New ${ }^{14} \mathrm{C}$ reference materials with activities of 15 and $50 \mathrm{pMC}$. Radiocarbon 40(1):295-7.

Leuschner HH, Delorme A. 1988. Tree-ring work in Goettingen. Absolute oak chronologies back to $6255 \mathrm{BC}$. PACT 22(II.5):123-32.

Levin I, Hesshaimer V. 2000. Radiocarbon - a unique tracer of global carbon cycle dynamics. Radiocarbon 42(1):69-80.

Linick TW, Suess HE, Becker B. 1985. La Jolla measurements of radiocarbon in South German oak tree-ring chronologies. Radiocarbon 27(1):20-32.

Löwemark L, Grootes PM. 2004. Large age differences between planktic foraminifers caused by abundance variations and Zoophycos bioturbation. Paleoceanog- 
raphy 19(2): PA2001, doi:10.1029/2003PA000949.

Maberly SC, Spence DHN. 1983. Photosynthetic inorganic carbon use by freshwater plants. Journal of Ecology 71(3):705-24.

Marshall M, Schlolaut G, Nakagawa T, Lamb H, Brauer A, Staff R, Bronk Ramsey C, Tarasov P, Gotanda K, Haraguchi T, Yokoyama Y, Yonenobu H, Tada R, Suigetsu 2006 Project Members. 2012. A novel approach to varve counting using $\mu \mathrm{XRF}$ and $\mathrm{X}$-radiography in combination with thin-section microscopy, applied to the Late Glacial chronology from Lake Suigetsu, Japan. Quaternary Geochronology 13:70-80.

Matsumoto K, Yokoyama Y. 2013. Atmospheric $\Delta^{14} \mathrm{C}$ reduction in simulations of Atlantic overturning circulation shutdown. Global Biogeochemical Cycles 27(2): 296-304.

McLean N, Bowring SA, Bowring JF, Condon DJ, Heizler M, Parrish R, Ramezani J, Schoene B. 2008. The EARTHTIME initiative: a review of accomplishments and promise. Presented at the International Geological Congress, 6-14 August 2008, Oslo.

Morse JW, Mackenzie FT. 1990. Geochemistry of Sedimentary Carbonates. Amsterdam: Elsevier. 707 p.

Munro MAR. 1984. An improved algorithm for crossdating tree-ring series. Tree-Ring Bulletin 44:17-27.

Nadeau M-J, Grootes PM, Voelker A, Bruhn F, Duhr A, Oriwall A. 2001. Carbonate ${ }^{14} \mathrm{C}$ background: Does it have multiple personalities? Radiocarbon 43(2A): 169-76.

Niu M, Heaton TJ, Blackwell PG, Buck CE. 2013. The Bayesian approach to radiocarbon calibration curve estimation: the IntCal13, Marine13, and SHCal13 methodologies. Radiocarbon 55(4), this issue.

Ojala AEK, Francus P, Zolitschka B, Besonen M, Lamoureux SF. 2012. Characteristics of sedimentary varve chronologies - a review. Quaternary Science Reviews 43:45-60.

Oswald WW, Anderson PM, Brown TA, Brubaker LB, Hu FS, Lozhkin AV, Tinner W, Kaltenrieder P. 2005. Effects of sample mass and macrofossil type on radiocarbon dating of arctic and boreal lake sediments. The Holocene 15(5):758-67.

Palmer J, Lorrey A, Turney CSM, Hogg A, Baillie M, Fifield K, Ogden J. 2006. Extension of New Zealand kauri (Agathis australis) tree-ring chronologies into Oxygen Isotope Stage (OIS) 3. Journal of Quaternary Science 21(7):779-87.

Pasquier-Cardin A, Allard P, Ferreira T, Hatté C, Coutinho R, Fontugne M, Jaudon M. 1999. Magmaderived $\mathrm{CO}_{2}$ emissions recorded in ${ }^{14} \mathrm{C}$ and ${ }^{13} \mathrm{C}$ content of plants growing in Furnas caldera, Azores. Journal of Volcanology and Geothermal Research 92(12):195-207.

Pearson GW. 1986. Precise calendrical dating of known growth-period samples using a "curve fitting" technique. Radiocarbon 28(2A):292-9.

Pilcher JR, Baillie MGL, Schmidt B, Becker B. 1984. A 7,272-year tree-ring chronology for western Europe.
Nature 312(5990):150-2.

Railsback LB. 2006. Some Fundamentals of Mineralogy and Geochemistry. [WWW document]. Department of Geology, University of Georgia. URL: www.gly.uga.edu/railsback/FundamentalsIndex.html.

Reimer PJ, Reimer RW. 2007. Radiocarbon dating: calibration. In: Elias SA, editor. Encyclopedia of Quaternary Science. Oxford: Elsevier. p 2941-9.

Reimer PJ, Hughen KA, Guilderson TP, McCormac G, Baillie MGL, Bard E, Barratt P, Beck JW, Buck CE, Damon PE, Friedrich M, Kromer B, Bronk Ramsey C, Reimer RW, Remmele S, Southon JR, Stuiver M, van der Plicht J. 2002. Preliminary report of the first workshop of the IntCal04 radiocarbon calibration/ comparison working group. Radiocarbon 44(3):65361.

Reimer PJ, Baillie MGL, Bard E, Bayliss A, Beck WJ, Bertrand C, Blackwell PG, Buck CE, Burr GS, Cutler KB, Damon PE, Edwards RL, Fairbanks RG, Friedrich M, Guilderson TP, Hughen KA, Kromer B, McCormac FG, Manning S, Bronk Ramsey C, Reimer RW, Remmele S, Southon JR, Stuiver M, Talamo S, Taylor FW, van der Plicht J, Weyhenmeyer CE. 2004. IntCal04 terrestrial radiocarbon age calibration, 0-26 cal kyr BP. Radiocarbon 46(3):1029-58.

Reimer PJ, Baillie MGL, Bard E, Beck JW, Blackwell PG, Buck CE, Burr GS, Edwards RL, Friedrich M, Guilderson TP, Hogg AG, Hughen KA, Kromer B, McCormac G, Manning S, Reimer RW, Southon JR, Stuiver M, van der Plicht J, Weyhenmeyer CE. 2006. Comment on "Radiocarbon calibration curve spanning 0 to 50,000 years B.P. based on paired ${ }^{230} \mathrm{Th} /{ }^{234} \mathrm{U} /$ ${ }^{238} \mathrm{U}$ and ${ }^{14} \mathrm{C}$ dates on pristine corals" by R.G. Fairbanks et al. and "Extending the radiocarbon calibration beyond 26,000 years before present using fossil corals" by T.-C. Chiu et al. (Quaternary Science Reviews 24 (2005) 1797-1808). Quaternary Science Reviews 25(7-8):855-62.

Reimer PJ, Baillie MGL, Bard E, Bayliss A, Beck JW, Blackwell PG, Bronk Ramsey C, Buck CE, Burr GS, Edwards RL, Friedrich M, Grootes PM, Guilderson TP, Hajdas I, Heaton TJ, Hogg AG, Hughen KA, Kaiser KF, Kromer B, McCormac FG, Manning SW, Reimer RW, Richards DA, Southon JR, Talamo S, Turney CSM, van der Plicht J, Weyhenmeyer CE. 2009. IntCa109 and Marine09 radiocarbon age calibration curves, 0-50,000 years cal BP. Radiocarbon 51(4): 1111-50.

Reimer PJ, Bard E, Bayliss A, Beck JW, Blackwell PG, Bronk Ramsey C, Buck CE, Cheng H, Edwards RL, Friedrich M, Grootes PM, Guilderson TP, Haflidason H, Hajdas I, Hatté C, Heaton TJ, Hoffman DL, Hogg AG, Hughen KA, Kaiser KF, Kromer B, Manning SW, Niu M, Reimer RW, Richards DA, Scott EM, Southon JR, Staff RA, Turney CSM, van der Plicht J. 2013. IntCa113 and Marine13 radiocarbon age calibration curves $0-50,000$ years cal BP. Radiocarbon 55(4), this issue. 
Richards DA, Dorale JA. 2003. Uranium-series chronology and environmental applications of speleothems. Uranium-Series Geochemistry 52(5):407-60.

Robinson LF, Henderson GM, Hall L, Matthews I. 2004. Climatic control of riverine and seawater uranium-isotope ratios. Science 305(5685):851-4.

Rozanski K, Stichler W, Gonfiantini R, Scott EM, Beukens RP, Kromer B, van der Plicht J. 1992. The IAEA ${ }^{14} \mathrm{C}$ intercomparison exercise 1990. Radiocarbon 34(3):506-19.

Rubin M, Lockwood JP, Friedamn I. 1987. Effects of volcanic emanations on carbon-isotope content of modern plants near Kilauea Volcano. In: Decker RW, Wright TL, Stauffer PH, editors. Volcanism in Hawaii. Washington, DC: US Government Printing Office. p 209-11.

Rudzka D, McDermott F, Baldini LM, Fleitmann D, Moreno A, Stoll H. 2011. The coupled $\delta^{13} \mathrm{C}$-radiocarbon systematics of three Late Glacial/early Holocene speleothems; insights into soil and cave processes at climatic transitions. Geochimica et Cosmochimica Acta 75(15):4321-39.

Sarnthein M, Grootes PM, Kennett JP, Nadeau M-J. 2007. ${ }^{14} \mathrm{C}$ reservoir ages show deglacial changes in ocean currents and carbon cycle. In: Schmittner A, Chiang JCH, Hemming SR, editors. Ocean Circulation: Mechanisms and Impacts - Past and Future Changes of Meridional Overturning. Geophysical Monograph 173. Washington, DC: American Geophysical Union. p 175-96.

Sarnthein M, Schneider B, Grootes PM. 2013. Peak glacial ${ }^{14} \mathrm{C}$ ventilation ages suggest major draw-down of carbon into the abyssal ocean. Climate of the Past Discussions 9:925-65.

Schaub M, Büntgen U, Kaiser KF, Kromer B, Talamo S, Andersen KK, Rasmussen SO. 2008. Lateglacial environmental variability from Swiss tree rings. Quaternary Science Reviews 27(1-2):29-41.

Schlolaut G, Marshall MH, Brauer A, Nakagawa T, Lamb HF, Staff RA, Bronk Ramsey C, Bryant CL, Brock F, Kossler A, Tarasov PE, Yokoyama Y, Tada R, Haraguchi T, Suigetsu 2006 Project Members. 2012. An automated method for varve interpolation and its application to the Late Glacial chronology from Lake Suigetsu, Japan. Quaternary Geochronology 13:52-69.

Schmidt B, Schwabedissen H. 1982. Ausbau des mitteleuropäischen Eichen-Jahrringkalenders bis in neolithische Zeit (2061 v.Chr.). Archäologisches Korrespondenzblatt 12:107-8.

Scott EM. 2003. The Third International Radiocarbon Intercomparison (TIRI) and the Fourth International Radiocarbon (FIRI) 1999-2002: results, analysis, and conclusions. Radiocarbon 45(2):135-408.

Scott EM, Cook GT, Naysmith P. 2010a. A report on phase 2 of the Fifth International Radiocarbon Intercomparison (VIRI). Radiocarbon 52(3):846-58.

Scott EM, Cook GT, Naysmith P. 2010b. The Fifth International Radiocarbon Intercomparison (VIRI): an as- sessment of laboratory performance in stage 3 . Radiocarbon 52(3):859-65.

Seard C, Camoin G, Yokoyama Y, Matsuzaki H, Durand N, Bard E, Sepulcre S, Deschamps P. 2010. Microbialite development patterns in the last deglacial reefs from Tahiti (French Polynesia; IODP Expedition \#310): implications on reef framework architecture. Marine Geology 279(1-4):63-86.

Sepulcre S, Durand N, Bard E. 2009. Mineralogical determination of reef and periplatform carbonates: calibration and implications for paleoceanography and radiochronology. Global and Planetary Change 66(12): $1-9$.

Singarayer JS, Richards DA, Ridgwell A, Valdes PJ, Austin WEN, Beck JW. 2008. An oceanic origin for the increase of atmospheric radiocarbon during the Younger Dryas. Geophysical Research Letters 35: L14707, doi:10.1029/2008GL034074.

Spurk M, Friedrich M, Hofmann J, Remmele S, Frenzel B, Leuschner HH, Kromer B. 1998. Revisions and extension of the Hohenheim oak and pine chronologies: new evidence about the timing of the Younger Dryas/ Preboreal transition. Radiocarbon 40(3):1107-16.

St. George S, Ault TR, Torbenson MCA. 2013. The rarity of absent growth rings in Northern Hemisphere forests outside the American Southwest. Geophysical Research Letters 40(14):3727-31.

Staff RA, Bronk Ramsey C, Nakagawa T, Suigetsu 2006 Project Members. 2010. A re-analysis of the Lake Suigetsu terrestrial radiocarbon dataset. Nuclear Instruments and Methods in Physics Research B 268(78):960-5.

Stuiver M, Braziunas TF. 1993. Modeling atmospheric ${ }^{14} \mathrm{C}$ influences and ${ }^{14} \mathrm{C}$ ages of marine samples to 10,000 BC. Radiocarbon 35(1):137-89.

Stuiver M, Braziunas TF. 1998. Anthropogenic and solar components of hemispheric ${ }^{14} \mathrm{C}$. Geophysical Research Letters 25(3):329-32.

Stuiver M, Quay PD. 1981. Atmospheric ${ }^{14} \mathrm{C}$ changes resulting from fossil fuel $\mathrm{CO}_{2}$ release and cosmic ray flux variability. Earth and Planetary Science Letters 53(3):349-62.

Stuiver M, Reimer PJ. 1993. Extended ${ }^{14} \mathrm{C}$ data base and revised CALIB $3.0{ }^{14} \mathrm{C}$ age calibration program. $R a$ diocarbon 35(1):215-30.

Stuiver M, Kromer B, Becker B, Ferguson CW. 1986. Radiocarbon age calibration back to 13,300 years BP and the ${ }^{14} \mathrm{C}$ age matching of the German oak and United States bristlecone pine chronologies. Radiocarbon 28(2B):969-79.

Stuiver M, Reimer PJ, Bard E, Beck JW, Burr GS, Hughen KA, Kromer B, McCormac G, van der Plicht J, Spurk M. 1998a. INTCAL98 radiocarbon age calibration, 24,000-0 cal BP. Radiocarbon 40(3):104183.

Stuiver M, Reimer PJ, Braziunas TF. 1998b. High-precision radiocarbon age calibration for terrestrial and marine samples. Radiocarbon 40(3):1127-51. 
Suess HE. 1970. Bristlecone pine calibration of the radiocarbon time-scale 5200 B.C. to the present. In: Olsson IU, editor. Proceedings of the Twelfth Nobel Symposium. Radiocarbon Variations and Absolute Chronology. New York: John Wiley and Sons. p 303-11.

Sulerzhitzky L. 1971. Radiocarbon dating of volcanoes. Bulletin of Volcanology 35(1):85-94.

Tennant RK, Jones RT, Brock F, Cook C, Turney CSM, Love J, Lee R. 2013. A new flow cytometry method enabling rapid purification of fossil pollen from terrestrial sediments for AMS radiocarbon dating. Journal of Quaternary Science 28(3):229-36.

Thomson J, Cook GT, Anderson R, Mackenzie AB, Harkness DD, McCave IN. 1995. Radiocarbon age offsets in different-sized carbonate components of deep-sea sediments. Radiocarbon 37(2):91-101.

Turney CSM, Coope GR, Harkness DD, Lowe JJ, Walker MJC. 2000. Implications for the dating of Wisconsinan (Weichselian) late-glacial events of systematic radiocarbon age differences between terrestrial plant macrofossils from a site in SW Ireland. Quaternary Research 53(1):114-21.

Turney CSM, Roberts RG, Jacobs Z. 2006. Archaeology: progress and pitfalls in radiocarbon dating. Nature 443(7108):E3.

Turney CSM, Fifield LK, Hogg AG, Palmer JG, Hughen K, Baillie MGL, Galbraith R, Ogden J, Lorrey A, Tims SG, Jones RT. 2010. The potential of New Zealand kauri (Agathis australis) for testing the synchronicity of abrupt climate change during the Last
Glacial Interval (60,000-11,700 years ago). Quaternary Science Reviews 29(27-28):3677-82.

Voelker AHL, Grootes PM, Nadeau M-J, Sarnthein M. 2000. Radiocarbon levels in the Iceland Sea from 25$53 \mathrm{kyr}$ and their link to the Earth's magnetic field intensity. Radiocarbon 42(3):437-52.

Vogel JS, Ognibene T, Palmblad M, Reimer P. 2004. Counting statistics and ion interval density in AMS. Radiocarbon 46(3):1103-9.

Wang X, Auler AS, Edwards RL, Cheng H, Cristalli PS, Smart PL, Richards DA, Shen C-C. 2004. Wet periods in northeastern Brazil over the past $210 \mathrm{kyr}$ linked to distant climate anomalies. Nature 432(7018):740-3.

Wigley TML, Briffa KR, Jones PD. 1984. On the average of correlated time series, with applications in dendroclimatology and hydrometeorology. Journal of Climate and Applied Meteorology 23(2):201-13.

Wohlfarth B, Possnert G. 2000. AMS radiocarbon measurements from the Swedish varved clays. Radiocarbon 42(3):323-33.

Yokoyama Y, Esat TM, Lambeck K, Fifield LK. 2000. Last ice age millennial scale climate changes recorded in Huon Peninsula corals. Radiocarbon 42(3):383401.

Zolitschka B. 2003. Dating based on freshwater and marine laminated sediments In: Mackay A, Battarbee RW, Birks J, Oldfield F, editors. Global Change in the Holocene. London: Edward Arnold Publishers. p 92106. 